\title{
Antituberculosis Activity of Brotowali (Tinospora crispa) Extract and Fractions against Mycobacterium tuberculosis using Microplate Alamar Blue Assay Method
}

\author{
Aktivitas Antituberkulosis Ekstrak dan Fraksi Batang Brotowali (Tinospora \\ crispa) terhadap Mycobacterium tuberculosis dengan Metode Microplate Alamar \\ Blue Assay
}

\author{
Retno Wahyuningrum ${ }^{1,2 *}$, Ritmaleni' ${ }^{1}$, Tatang Irianti' ${ }^{1}$, Subagus Wahyuono ${ }^{1}$, Takushi Kaneko ${ }^{3}$, Titik \\ Nuryastuti 4 \\ 1Faculty of Pharmacy Universitas Gadjah Mada, Yogyakarta, Indonesia \\ 2Faculty of Pharmacy Universitas Muhammadiyah Purwokerto, Indonesia \\ ${ }^{3}$ Tuberculosis Alliance, New York, United State \\ ${ }^{4}$ Faculty of Medicine Universitas Gadjah Mada, Yogyakarta, Indonesia
}

\begin{abstract}
Tuberculosis (TB), in which caused by pathogenic bacteria, Mycobacterium tuberculosis, has become the major causes of death among all of infectious diseases. The increasing incidence of multidrug-resistant tuberculosis (MDR-TB) and extensively drug-resistant tuberculosis (XDR-TB) has created a need to discover a new antituberculosis drug candidate. The aim of this study was to screen extract and fractions of Tinospora crispa for activity against Mycobacterium tuberculosis H37Rv using the Microplate Alamar Blue Assay (MABA) method. T. crispa extract was prepared by maceration in ethanol (96\%) and antituberculosis activity was carried out using MABA method. The result of this study showed that ethanolic extract of T. crispa exhibit antituberculosis activity with minimum inhibition concentration of $12.5 \mathrm{mg} / \mathrm{ml}$.
\end{abstract}

\section{ABSTRAK}

Tuberkulosis (TB) adalah penyakit yang disebabkan oleh infeksi Mycobacterium tuberculosis dan menjadi penyakit infeksi yang menyebabkan paling banyak kematian di dunia. Daruratnya penyakit TB dan meningkatnya kasus multidrug-resistant tuberculosis (MDR-TB) dan XDR-TB ini mendorong dilakukannya banyak penelitian dan pengembangan obat antiTB baru. Penelitian ini bertujuan untuk mengetahui aktivitas antituberkulosis batang Brotowali. Batang Brotowali kering diekstraksi dengan metode maserasi menggunakan pelarut etanol 96\%. Uji aktivitas antituberkulosis secara in vitro terhadap M. tuberculosis H37Rv dilakukan dengan metode Microplate Alamar Blue Assay (MABA). Hasil penelitian menunjukkan bahwa ekstrak etanol batang Brotowali memiliki aktivitas antituberkulosis terhadap M. tuberculosis H37Rv dengan konsentrasi hambat minimum (KHM) sebesar 12,5 mg/ml.

\section{INTRODUCTION}

Tuberculosis (TB) is an infectious disease and the second leading cause of death from a single infectious disease in the world after human immunodeficiency virus (HIV) (Prabu et al., 2015). In 2014, TB had caused 1.5 million of deaths (World Health Organization, 2015). It remains a major global health problem. This disease is caused by Mycobacterium tuberculosis, an intracelluler obligate and aerobic bacillus that multiplies within macrophage.

TB treatment is generally consist of combination of four first line drugs: isoniazid, rifampicin, ethambutol, and pyrazinamide for two

Correspondence author: Retno Wahyuningrum

Email : retno_aulady@yahoo.com months and followed by four additional months of isoniazid and rifampicin therapy (Nguta et al., 2015). Unfortunately, in the last few decades, multi-drug resistant (MDR-TB) was arised. MDRTB is caused by strain of M. tuberculosis that are resistant to isoniazid and rifampicin (Keshavjee and Farmer, 2012). In 2014, there were 480.000 MDR-TB cases and estimated 190.000 people died because of this disease (World Health Organization, 2015). Approximately $9.6 \%$ of the total MDR-TB cases are classified as extensively drug-resisten tuberculosis (XDR-TB) (Nguta et al., 2015). In this cases, M. tuberculosis strain is not only resistant to isoniazid and rifampicin, but also resistant to any fluoroquinolones and to at least first line injectable antituberculosis drug, i.e amikacin, capreomycin, and kanamycin. The 
emergence of MDR-TB and followed by XDR-TB remains a major challenge to global health. This condition led to an urgent need to discover a new antituberculosis drug. Many researches are focused on the discovery and development of new antituberculosis drugs from natural product (Chinsembu, 2016). It can be done by screen novel compound from a natural product such as plant species (Alvin et al., 2014). Natural products are considered as potential anti-TB agents (Nguta et al., 2015)

Tinospora crispa (L.) Miers ex Hook.f.Thoms) is a member of Menispermaceae. It is widely known as Brotowali in Indonesia. It is widely distributed over tropical and subtropical Asia including India, Thailand, Vietnam, Philippines, Indonesia, and Malaysia (Chang et al., 2015). This plant is commonly used as traditional medicine, especially its stem. The stem of T. crispa is traditionally used to treat tuberculosis. Some preliminary research reported the activity of $T$. crispa against M. tuberculosis. Ethanolic extract of T. crispa from Laos has antimycobacterial activity against $\mathrm{M}$. tuberculosis with minimum inhibitory concentration (MIC) 2,43-96,2 $\mu \mathrm{g} / \mathrm{ml}$ (Elkington et al., 2014). But there has been no report about the antimycobacterial activity of $T$. crispa that grows in Indonesia and its fractions or isolates. The present study determined the antimycobacterial activity of ethanolic extract of T. crispa collected from Indonesia using microplate alamar blue assay (MABA) method.

\section{METHODOLOGY}

An antituberculosis activity using MABA assay was conducted in Tuberculosis Laboratory (BSL 2+), Faculty of Medicine, Universitas Gadjah Mada. Extraction and fractionation procedures were conducted in Department of Pharmaceutical Biology, Faculty of Pharmacy, Universitas Gadjah Mada.

\section{Bacterial strain}

M. tuberculosis H37Rv was obtained from Tuberculosis Laboratory, Faculty of Medicine, Universitas Gadjah Mada. This bacteria was subcultured on Lowenstein Jensen (LJ) medium. Suspension of log phase M. tuberculosis H37RV was prepared in $0.04 \%(\mathrm{v} / \mathrm{v})$ Tween 80 and $0.2 \%$ bovine serum albumin (Sigma) so that their turbidities matches that of a Mc.Farland no.1 turbidity standard. The turbidity was examined by weighing method (Kemenkes RI, 2012). Suspension was further diluted 1:25 in 7H9GC broth $4.7 \mathrm{~g}$ of Middlebrook $7 \mathrm{H} 9$ broth base, $20 \mathrm{~mL}$ of $10 \%$ glycerol, $880 \mathrm{~mL}$ of distilled water, $100 \mathrm{~mL}$ of OADC (oleic acid, albumin, dextrose, catalase)).

\section{Chemicals and media}

Middlebrook $7 \mathrm{H} 9$ broth (Difco), glycerol (Merck), OADC (oleic acid, albumin, dextrose, catalase; Becton Dickinson), Tween 80 (Sigma), Alamar Blue reagent (Invitrogen), sterile water, dimethyl sulfoxide, isoniazide (Fluka), rifampicin (Sigma), ethanol 96\%, n-hexane, ethyl acetate, silika gel $\mathrm{F}_{254}$ plate (Merck), ceric sulfate.

\section{Plant material}

Stems of T. crispa were collected in February 2016 from Sleman, Yogyakarta, Indonesia, and were authenticated in Department of Pharmaceutical Biology, Faculty of Pharmacy, Universitas Gadjah Mada.

\section{Extraction}

Dried and ground plant material (500 g) was extracted at room temperature by maceration method with ethanol $96 \%$ and repeated twice. Extraction process was done twice to get more effective extraction so that more compounds can be extracted. The extracts were then condensed using a Buchi rotary evaporator (rotavapor).

\section{Fractionation}

The extract was fractionated using trituration method. The ethanolic extract $(5 \mathrm{~g})$ was added with n-hexane and then shaken for 10 minutes. After shaking, it was filtered with sinterglass, then the filtrate were collected. The fractionation with n-hexane was conducted three times. The collected filtrate was condensed using a Buchi rotary evaporator (rotavapor) and it was called n-hexane fraction (F1). The residue, called n-hexane non-soluble fraction (F2), was then added with ethyl acetate and then shaken for 10 minutes. After shaking, it was filtered with sinterglass and the filtrate were collected. The fractionation with ethyl acetate was conducted three times. The collected filtrate condensed using a Buchi rotary evaporator (rotavapor) and called ethyl acetate fraction (F3). The residue was called ethyl acetate non-soluble fraction (F4).

\section{Microplate Alamar Blue Assay (MABA) antituberculosis test}

Antimycobacterial assay was perform using the Microplate Alamar blue assay (MABA) (Franzblau et al., 1998). This assay was performed in 96-well microplates (Iwaki). Outer perimeter wells were filled with $200 \mu \mathrm{L}$ of sterile water to minimize evaporation of the medium in the experimental wells during incubation. One hundred microliters of 7H9GC broth were added to experimental wells. One hundred microliters of $100 \mathrm{mg} / \mathrm{ml}$ sample solution (extract 
or fraction) were added to the wells in row B and $\mathrm{C}$ in columns 2,3 , and 4 . By using micropippete, $100 \mu \mathrm{L}$ was trasferred from row $\mathrm{C}$ to $\mathrm{D}$ and the contents of the wells were mixed well. This dilutions were continued through row G, and $100 \mu \mathrm{L}$ of excess medium was discarded from the wells in row $\mathrm{G}$. Final extract concentration were $100 ; 50 ; 25 ; 12.5 ; 6.25$ and $3.125 \mathrm{mg} / \mathrm{ml}$ (from row $B$ to $G$ ). In the previous assay (not reported in this paper), we used final concentration ranges of 62.5 to $2000 \mu \mathrm{g} / \mathrm{ml}$, but the result showed that it were not active. So, in the last assay, we used greater concentration of samples up to $100 \mathrm{mg} / \mathrm{mL}$. Row B to D columns 8 were used to isoniazide $10 \mu \mathrm{g} / \mathrm{mL}$ as positive controls. Row B to D columns 9 were used to rifampicin $10 \mu \mathrm{g} / \mathrm{mL}$ as positive controls. Row B to D columns 10 were used to dimethyl sulfoxide $4 \%$ as solvent controls. The wells in columns 11 served as sample-free (inoculum only) controls. One hundred microliters of $M$. tuberculosis suspension was added to the wells in row $B$ to $G$ in columns 2 to 11 yielding a final volume of $200 \mu \mathrm{L}$ per well. The plates were sealed with parafilm and were incubated at $37^{\circ} \mathrm{C}$ for 5 days. Starting at day 6 of incubation, $50 \mu \mathrm{L}$ of freshly prepared $1: 1$ mixture of Alamar Blue reagent and 10\% Tween 80 was added to well B11 and plate were reincubated at $37^{\circ} \mathrm{C}$ for $24 \mathrm{~h}$. If $\mathrm{B} 11$ became pink by $24 \mathrm{~h}$, the reagent mixture was added to the entire plate (if the well remained blue, the reagent mixture would be added to another control well and the result would be read on the following day). The microplates were resealed with parafilm and were incubated for an additional $24 \mathrm{~h}$ at $37^{\circ} \mathrm{C}$, and the colors of all well were recorded. A blue color in the well was interpreted as no growth and a pink color was scored as growth. The Minimum Inhibitory Concentration (MIC) was defined as the lowest concentration of samples which prevented a color change from blue to pink.

\section{RESULTS AND DISCUSSION}

T. crispa is a well-known source of herbal plant which is used traditionally as medications for diabetes mellitus, hypercholesterolemia and also hepatoprotective (Abu et al., 2015). In order to screen the potentiality of $T$. crispa as antituberculosis candidate, ethanolic extract of the stem of $T$. crispa was tested againts $M$. tuberculosis using Microplate Alamar Blue Assay (MABA).

MABA is a microplate method that used as high-throughput screen antituberculosis activity of samples. This method used Alamar blue, a resazurin-based oxidation-reduction based indicator. This indicator delivered colorimetric MIC for M. tuberculosis in 14 days (Franzblau et al., 1998). In this research, MIC for Ethanolic extract of Brotowali was available after 7 days of incubation. MABA is more effective and efficient than other method to determine drug or samples susceptibilities. M. tuberculosis is a slow growing mycobacteria and this method has significantly decrease the time to get the result. Biosafety cabinet, autoclave, and $37^{\circ} \mathrm{C}$ incubator are minimum major equipment to perform MABA.

Alamar blue dye is general indicator of celular growth and or viability; the blue and nonfluorescent. It is in blue color in the oxidized state, but it turns pink when reduced due to bacterial metabolism. Therefore, the growth of $M$. tuberculosis can be measured with fluorometer or spectrophotometer or determined by a visual color change (Collins and Franzblau, 1997). This is the major advantage of MABA. In this research, the growth of $M$. tuberculosis was determined by visual color change, without the use of specialized equipment. Collins and Franzblau (1997) reported that there were no statistically significant differences among MICs determined by fluorometric and visual MABA. The two colors (blue and pink) can be easily differentiated with the naked eye. Visual readout is the most frequently used in evaluation of antituberculosis compounds (Franzblau et al., 2012).

MABA has a low possibility to resulting aerosols of $M$. tuberculosis suspension from well, so it can reduce the possibility of researcher may be infected during the assay. It is the other advantage of MABA method from biosafety perspective. $\mathrm{H} 37 \mathrm{Rv}$ is a virulent strain of $M$. tuberculosis. This strain is still sensitive to rifampicin and isoniazide as antituberculosis drug used in tuberculosis therapy. H37Rv is the most strain used by laboratories in antituberculosis screening (Franzblau et al., 2012).

Different culture media are in use for the isolation of mycobacteria. The most common is Lowenstein-Jensen (LJ) medium. It is an egg based medium with high concentrations of malachite green to overcome contamination with other bacteria. However, culture on it is long (3 weeks to 3 months for $M$. tuberculosis) and time consuming. In this research, we used Middlebrook 7H9 broth-based as the most media used in microplate-based assay. Glycerol was added as carbon source for culturing $M$. tuberculosis. While Tween 80 was used to minimize clumping of mycobacteria during growth. 
Table I. Antimycobacterial activity results of T. crispa ethanolic extract and its fraction using MABA method

\begin{tabular}{|c|c|c|c|c|}
\hline No & Sample name & Code & Concentration (mg/ml) & Result \\
\hline \multirow{6}{*}{1} & \multirow{6}{*}{ Ethanolic extract of $T$. crispa stem } & \multirow{6}{*}{ EEB } & 100 & Active \\
\hline & & & 50 & Active \\
\hline & & & 25 & Active \\
\hline & & & 12.5 & Active \\
\hline & & & 6.25 & Not active \\
\hline & & & 3.125 & Not active \\
\hline \multirow{6}{*}{2} & \multirow{6}{*}{ n-hexane soluble fraction } & \multirow{6}{*}{$\mathrm{F} 1$} & 2 & Not active \\
\hline & & & 1 & Not active \\
\hline & & & 0.5 & Not active \\
\hline & & & 0.25 & Not active \\
\hline & & & 0.125 & Not active \\
\hline & & & 0.0625 & Not active \\
\hline \multirow{6}{*}{3} & \multirow{6}{*}{ n-hexane non soluble fraction } & \multirow{6}{*}{$\mathrm{F} 2$} & 2 & Not active \\
\hline & & & 1 & Not active \\
\hline & & & 0.5 & Not active \\
\hline & & & 0.25 & Not active \\
\hline & & & 0.125 & Not active \\
\hline & & & 0.0625 & Not active \\
\hline \multirow{6}{*}{4} & \multirow{6}{*}{ Ethyl acetate soluble fraction } & \multirow{6}{*}{ F3 } & 2 & Not active \\
\hline & & & 1 & Not active \\
\hline & & & 0.5 & Not active \\
\hline & & & 0.25 & Not active \\
\hline & & & 0.125 & Not active \\
\hline & & & 0.0625 & Not active \\
\hline \multirow{6}{*}{5} & \multirow{6}{*}{ Ethyl acetate non soluble fraction } & \multirow{6}{*}{$\mathrm{F} 4$} & 2 & Not active \\
\hline & & & 1 & Not active \\
\hline & & & 0.5 & Not active \\
\hline & & & 0.25 & Not active \\
\hline & & & 0.125 & Not active \\
\hline & & & 0.0625 & Not active \\
\hline 6 & Isoniazid $10 \mu \mathrm{g} / \mathrm{ml}$ & $\mathrm{K}+$ & 0.01 & Active \\
\hline 7 & Rifampisin $10 \mu \mathrm{g} / \mathrm{ml}$ & $\mathrm{K}+$ & 0.01 & Active \\
\hline 8 & DMSO 4\% & Кр & & Not active \\
\hline
\end{tabular}

Sample was categorized as active if it can prevent a color change from blue to pink. In this study, we tested extract and fraction of T. crispa with $100 \mathrm{mg} / \mathrm{ml}$ as the highest concentration because it were not active under $100 \mu \mathrm{g} / \mathrm{ml}$. Most paper suggested that plants extract considered had significant antituberculosis activity if MIC was $<100 \mu \mathrm{g} / \mathrm{mL}$. There were many different reference to analyze the antituberculosis activity of plant extracts. In previous study, plants extract were considered active against $M$. tuberculosis if MIC was $<100 \mu \mathrm{g} / \mathrm{mL}$ (Borges-Argáez et al., 2007; Gautam et al., 2007; Okunade et al., 2004), $<200 \mu \mathrm{g} / \mathrm{mL}$ (Camacho-Corona et al., 2008; Tosun et al., 2004), < $1600 \mu \mathrm{g} / \mathrm{mL}$ (Mohamad et al., 2011), $\leq 2048 \mu \mathrm{g} / \mathrm{ml}$ (Tekwu et al., 2012). In other paper, the antimicrobial activity of plant extracts was classified as significant (MIC $\leq 100 \mu \mathrm{g} / \mathrm{mL}$ ), moderate $(100<$ MIC $<625 \mu \mathrm{g} / \mathrm{mL}$ ), or weak (MIC $>625 \mu \mathrm{g} / \mathrm{mL}$ ) (Kuete, 2010). Because of ethanolic extract of Brotowali exhibited antituberculosis activity against $M$. tuberculosis $\mathrm{H} 37 \mathrm{Rv}$ with MIC $12.5 \mathrm{mg} / \mathrm{mL}$, so we interpreted that this activity was weak.

The results of antituberculosis assay of extract and its fractions against $M$. tuberculosis H37Rv are shown in Table 1 . These results showed that from T. crispa extract and fractions tested, ethanolic extract of Brotowali exhibited antituberculosis activity against $M$. tuberculosis H37Rv with MIC $12.5 \mathrm{mg} / \mathrm{mL}$. This was contradictive with the result of previous research 


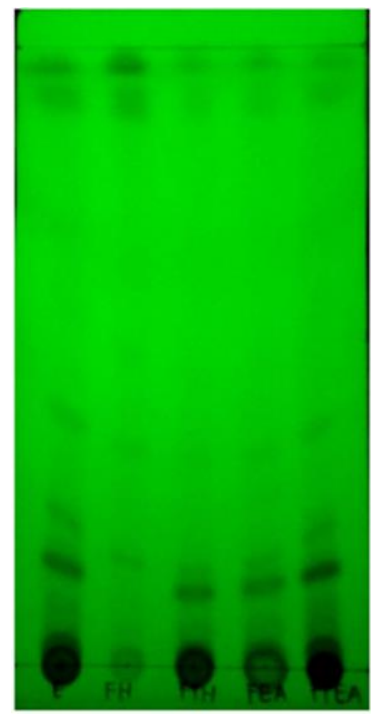

A

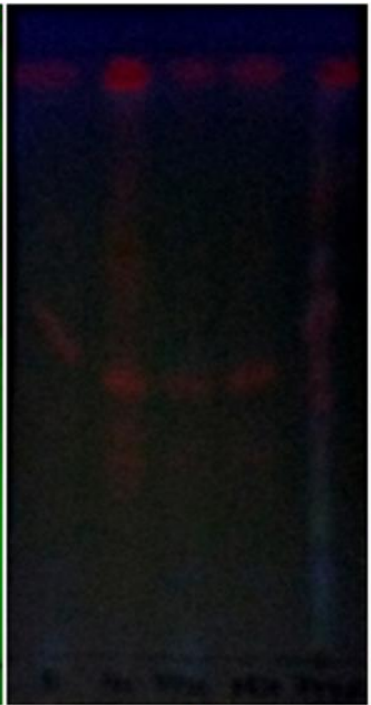

B

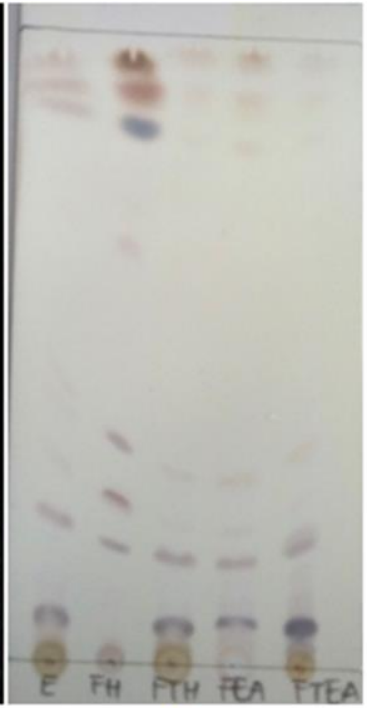

C

Figure 1. Thin layer chromatography profile of Brotowali ethanolic extract and its fraction on silica gel 60 $\mathrm{F}_{254}$ plate as stationary phase, and chloroform:methanol (9:1) as mobile phase. A : under uv $254 \mathrm{~nm}$ detection; B : under uv $366 \mathrm{~nm}$ detection; $\mathrm{C}$ : after sprayed by ceric sulfate.

that ethanolic extract of T. crispa from Laos has antimycobacterial activity against $M$. tuberculosis with minimum inhibitory concentration (MIC) $2,43-96,2 \mu \mathrm{g} / \mathrm{mL}$. The difference of plant materials collection location could be one of the reason of this different results. Different type of soil, different organic component in soil can influence the secondary metabolite contains in plant. This can affect the biological and pharmacology activity of the plant.

The fractions (F1, F2, F3, and F4) were result of separation procedures of T. crispa extract. This separation procedures were conducted to separate the compound content in the extract based on its polarity properties. nhexane fraction (F1) contains non polar compounds, n-hexane non-soluble fraction contains compounds that its more polar than F1. Ethyl acetate fraction (F3) contains semi-polar compounds and ethyl acetate non-soluble fraction (F4) contains polar compounds. So, if the result of antituberculosis assay of fractions were active and potential to be developed as new antituberculosis drug candidates, it will become easier to isolate the active compound from the active fraction. Unfortunately, all fractions did not exhibited antituberculosis activity against M.tuberculosis H37Rv.

Based on chromatogram on figure 1 , Brotowali ethanolic extract axhibited a clear seperation using chloroform and methanol as mobile phase. n-hexane soluble fraction (F1) contains non-polar compounds dominantly, while the polar compounds contained in the ethyl acetate non soluble fraction (F4). T. crispa contains a wide range of secondary metabolites such as alkaloids, terpens, flavons and phenolics (Koay and Koay, 2013). This compounds exhibited antitubercular activity (Okunade, et al., 2004; Garcia et al., 2012). But, in this research, we did not do any test to find out which compounds in $T$. crispa extract had the responsibility of the antituberculosis activity.

\section{CONCLUSIONS}

In conclusion, our data show that ethanolic extract of $T$. crispa has weak antituberculosis activity against M. tuberculosis with MIC of 12.5 $\mathrm{mg} / \mathrm{ml}$.

\section{ACKNOWLEDGEMENTS}

We would like to thank Tuberculosis Alliance and Faculty of Pharmacy, Universitas Gadjah Mada for the funding of this research.

\section{REFERENCES}

Abu, M.N., Samat, S., Kamarapani, N., Nor Hussein, F., Wan Ismail, W.I., Hassan, H.F., 2015. Tinospora crispa Ameliorates Insulin Resistance Induced by High Fat Diet in 
Wistar Rats. Evid. Based Complement. Alternat. Med. 2015, 1-6.

Alvin, A., Miller, K.I., Neilan, B.A., 2014. Exploring the potential of endophytes from medicinal plants as sources of antimycobacterial compounds. Microbiol. Res. 169, 483-495.

Borges-Argáez, R., Canche-Chay, C.I., PeñaRodríguez, L.M., Said-Fernández, S., MolinaSalinas, G.M., 2007. Antimicrobial activity of Diospyros anisandra. Fitoterapia 78, 370372.

Camacho-Corona, M. del R., Ramírez-Cabrera, M.A., Santiago, O.G.-, Garza-González, E., Palacios, I. de P., Luna-Herrera, J., 2008. Activity against drug resistant-tuberculosis strains of plants used in Mexican traditional medicine to treat tuberculosis and other respiratory diseases. Phytother. Res. 22, 82-85.

Chang, C.-C., Ho, S.L., Lee, S.-S., 2015. Acylated glucosylflavones as $\alpha$-glucosidase inhibitors from Tinospora crispa leaf. Bioorg. Med. Chem. 23, 3388-3396.

Chinsembu, K.C., 2016. Tuberculosis and nature's pharmacy of putative anti-tuberculosis agents. Acta Trop. 153, 46-56.

Collins, L., Franzblau, S.G., 1997. Microplate alamar blue assay versus BACTEC 460 system for high-throughput screening of compounds against Mycobacterium tuberculosis and Mycobacterium avium. Antimicrob. Agents Chemother. 41, 10041009.

Elkington, B.G., Sydara, K., Newsome, A., Hwang, C.H., Lankin, D.C., Simmler, C., Napolitano, J.G., Ree, R., Graham, J.G., Gyllenhaal, C., Bouamanivong, S., Souliya, O., Pauli, G.F., Franzblau, S.G., Soejarto, D.D., 2014. New finding of an anti-TB compound in the genus Marsypopetalum (Annonaceae) from a traditional herbal remedy of Laos. J. Ethnopharmacol. 151, 903-911.

Franzblau, S.G., DeGroote, M.A., Cho, S.H., Andries, K., Nuermberger, E., Orme, I.M., Mdluli, K., Angulo-Barturen, I., Dick, T., Dartois, V., Lenaerts, A.J., 2012. Comprehensive analysis of methods used for the evaluation of compounds against Mycobacterium tuberculosis. Tuberculosis 92, 453-488.

Franzblau, S.G., Witzig, R.S., Mclaughlin, J.C., Torres, P., Madico, G., Hernandez, A., Degnan, M.T., Cook, M.B., Quenzer, V.K., Ferguson, R.M., Gilman, R.H., 1998. Rapid, low-technology MIC determination with clinical Mycobacterium tuberculosis isolates by using the microplate Alamar Blue assay. J. Clin. Microbiol. 36, 362-366.
García, A., Bocanegra-García, V., Palma-Nicolás, J.P., Rivera, G., 2012. Recent advances in antitubercular natural products. Eur. J. Med. Chem. 49, 1-23.

Gautam, R., Saklani, A., Jachak, S.M., 2007. Indian medicinal plants as a source of antimycobacterialagents. Ethnopharmacol. 110, 200-234.

Kementerian Kesehatan Republik Indonesia, 2012, Petunjuk Teknis Pemeriksaan Biakan, Identifikasi, Dan Uji Kepekaan Mycobacterium tuberculosis pada Media Padat, Jakarta

Keshavjee, S., Farmer, P.E., 2012. Tuberculosis, Drug Resistance, and the History of Modern Medicine. N. Engl. J. Med. 367, 931-936.

Koay, Y., Koay, F., 2013. A Review of the Secondary Metabolites and Biological Activities of \&lt;i\&gt;Tinospora crispa\&lt;/i\&gt; (Menispermaceae). Trop. J. Pharm. Res., 12, 641-649

Kuete, V., 2010. Potential of Cameroonian Plants and Derived Products against Microbial Infections: A Review. Planta Med. 76, 14791491.

Mohamad, S., Zin, N.M., Wahab, H.A., Ibrahim, P., Sulaiman, S.F., Zahariluddin, A.S.M., Noor, S.S.M., 2011. Antituberculosis potential of some ethnobotanically selected Malaysian plants. J. Ethnopharmacol. 133, 1021-1026.

Nguta, J.M., Appiah-Opong, R., Nyarko, A.K., Yeboah-Manu, D., Addo, P.G.A., 2015. Current perspectives in drug discovery against tuberculosis from natural products. Int. J. Mycobacteriology 4, 165-183.

Okunade, A.L., Elvin-Lewis, M.P.F., Lewis, W.H., 2004. Natural antimycobacterial metabolites: current status. Phytochemistry 65, 1017-1032.

Prabu, A., Hassan, S., Prabuseenivasan, Shainaba, A.S., Hanna, L.E., Kumar, V., 2015. Andrographolide: A potent antituberculosis compound that targets Aminoglycoside 2' $\mathrm{N}$-acetyltransferase in Mycobacterium tuberculosis. J. Mol. Graph. Model. 61, 133140.

Tekwu, E.M., Askun, T., Kuete, V., Nkengfack, A.E., Nyasse, B., Etoa, F.-X., Beng, V.P., 2012. Antibacterial activity of selected Cameroonian dietary spices ethnomedically used against strains of Mycobacterium tuberculosis. J. Ethnopharmacol. 142, 374-382.

Tosun, F., Kızılay, Ç.A., Şener, B., Vural, M., Palittapongarnpim, $\quad$ P., 2004. Antimycobacterial screening of some 
Turkish plants. J. Ethnopharmacol. 95, 273275.
World Health Organization, 2015. Global tuberculosis report 2015. World Health Organization, [S.l.]. 